\title{
Global Mental Health: What is Your Role in This Movement?
}

\author{
Saúde Mental Global: Qual o Seu Papel Neste Movimento?
}

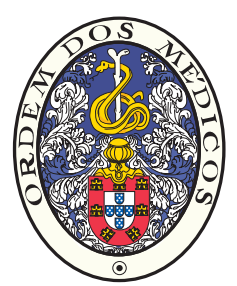

Mariana PINTO DA COSTA $\bigotimes^{1,2}$

Acta Med Port 2015 Mar-Apr;28(3):275-276

Keywords: Global Health; Mental Disorders.

Palavras-chave: Perturbações Mentais; Saúde Global.

There is no health without society. There is no health without mental health.

Health and society are intimately linked. Health depends on wealth, on having the means to enable people to achieve their potential. Mental and physical health are intimately linked: mental health is an integral part of health.

\section{One's mental health is vital}

One's self-concept, perceptions and motivation, is influenced by the emotional, psychological and social well-being. These, obviously influence physical health, relationships and functioning. Besides, co-morbidities can occur, and these are actually the rule, not the exception. Also, the impact of a comorbid mental and physical illness on disability is not only additive, but even potentiated. ${ }^{1}$ Therefore, a paradigm shift should rather address these as multi-morbidities, given the likelihood of mental, physical and social problems that a living person throughout time can reach to have.

Mental disorders are independently associated with a substantial excess in all-cause mortality risk. For instance, people with severe mental illness often live in social deficiencies, being less likely to receive medical checks and to be provided with evidence based treatment, being discriminated also by health services. ${ }^{2}$ Certainly, social justice is the key and means that people with mental illness should have the same rights than any person.

Worldwide, one in four people is affected by mental or neurological disorders at some point in their lives ${ }^{3}$

So, perhaps you are one of this people. Still, despite the high prevalence of mental disorders, stigma and discrimination, including self-stigma, seem to be discouraging people to speak about their problems.

Mr. Bondevik, while serving his first term as Prime Minister of Norway, publicly announced that he was suffering from a depressive episode, contributing immensely to the openness of mental health problems and fighting stigma.
So, if the prime minister can talk about his mental health problems, why can't you do it too?

Global, perceives a world view perspective, denoting a dynamic approach.

Globalization refers to a wide-reaching system characterized by economic, political, technological, cultural and environmental changes. These transformations, especially triggered by the communication revolution and the massive international migration flows, generated the possibility to bring people closer, enabling information to be quickly shared, allowing the comparison between realities, which can put ideologies in question on occasion, and urge the will to get similar lifestyles.

Still, globalization cannot be turned back. The challenge is to make it an instrument of opportunity and inclusion for all, giving attention to the core values of autonomy, equality, empowerment, and respect for diversity and human rights, towards an international cooperation that leads to mutual benefits.

We can all learn from each other and the world is now a smaller place. In fact, the enthusiasm of people that participate in exchange programmes anywhere: low, middle and high income countries, is an example that illustrates the advantages of a broader base of knowledge in health with a diversity background. It raises awareness to the necessity to pay attention to cultural and local specific circumstances, and at the same time, to foster features of universal importance. These global changes are restructuring human societies, leading to new patterns of health and disease and reshaping the determinants of health across the life course. That is why global health cannot be seen as isolated from its context.

The high prevalence and burden of neuropsychiatric disorders draw attention to the importance of public mental health

In fact, the upcoming of global mental health can be

\footnotetext{
1. Psychiatry Trainee. Hospital de Magalhães Lemos. University of Porto. Porto. Portugal.

2. President. European Federation of Psychiatric Trainees. Brussels. Belgium.

$\triangle$ Autor correspondente: Mariana Pinto da Costa. mariana.pintodacosta@gmail.com

Recebido: 05 de Junho de 2015 - Aceite: 05 de Junho de 2015 | Copyright $\odot$ Ordem dos Médicos 2015
} 
stimulated by advocacy, entailing a greater role for all the players of society to speak as patient advocators': users, families, health professionals, community leaders and decision-makers.

According to the World Health Organization (WHO), mental health is a state of well-being in which the individual realizes his or her own abilities, can cope with the normal stresses of life, can work productively and fruitfully, and is able to make a contribution to his or her community.

Since ups and downs are part of the human life experience, hopefully in most of the times in this state of equilibrium, life shall be pleasant and appreciated, but at other times it can be unpleasant and upsetting. Plus, the experience of being present in the world cannot be detached from how one feels in his or her environment - indeed mind, body and milieu are deeply linked.

\section{There is no health, without society. There is no health,} without mental health.

Public health approaches must balance risks and benefits. It is nevertheless unanimous that mental health promotion and prevention of disorders are particularly important. Meanwhile, in order to achieve improvements in public mental health, societies must tackle: damaging childhood environments, low socio-economic status, poor education, unemployment, poverty, social isolation,

\section{REFERENCES}

1. Goodell S, Druss BG, Walker ER. Mental disorders and medical comorbidity. The Synthesis Project. Research Synthesis Report. No 21, February 2011. The Robert Wood Johnson Foundation Website. [consulted 2015 Jun 5]. Available from: http://www.rwjf.org/en/researchpublications/find-rwjf-research/2011/02/mental-disorders-and-medicalcomorbidity.html.

2. Prince M, Patel V, Saxena S, Maj M, Maselko J, Phillips MR, et al. No health without mental health. Lancet. 2007;370:859-77.

3. World Health Organization (WHO), Geneva. World health report. 2011. exclusion, inequalities and experiences of violence. ${ }^{4}$

Mental health must concern itself not only with mental illness, but also with health and well-being. Within Europe, significant health gains have been seen in those populations that have experienced improvements in the environment where people are born, grow, live and work. Nevertheless, inequalities within and between countries endure. The WHO European Review of Social Determinants of Health and the Health Divide has called for action in the social and economic spheres to achieve greater health equity, with less deficits and a more balanced social gradient. ${ }^{5}$

Acknowledging the importance of this endeavour, the $23^{\text {rd }}$ Forum of the European Federation of Psychiatric Trainees (EFPT), taking place in Portugal this year, elected "Global mental health" as motto, and welcomes, for the first time at this Forum, colleagues from different regions of the world, beyond Europe.

Global mental health is the area of study, research and practice that places a priority on improving mental health and achieving equity in mental health for all people worldwide, aiming to reinforce mental health all over the world. It is necessary that mental health truly becomes a matter that concerns everybody and is of everybody's interest.

We are all in this together!

[consulted 2015 Jun 5]. Available from: http://www.who.int/whr/2001/ media_centre/press_release/en/

4. Wahlbeck K. Public mental health: the time is ripe for translation of evidence into practice. World Psychiatry. 2015;14:36-42.

5. Marmot M, Allen J, Bell R, Bloomer E, Goldblatt P, Consortium for the European Review of Social Determinants of Health and the Health Divide. WHO European review of social determinants of health and health divide. Lancet. 2012;380:1011-29. 


\section{Mariana PINTO DA COSTA \\ Global Mental Health: What is Your Role in This Movement?}

Acta Med Port 2015:28:275-276

Publicado pela Acta Médica Portuguesa, a Revista Científica da Ordem dos Médicos

Av. Almirante Gago Coutinho, 151

1749-084 Lisboa, Portugal.

Tel: +351218428 215

E-mail: submissao@actamedicaportuguesa.com

www.actamedicaportuguesa.com

ISSN:0870-399X | e-ISSN: 1646-0758

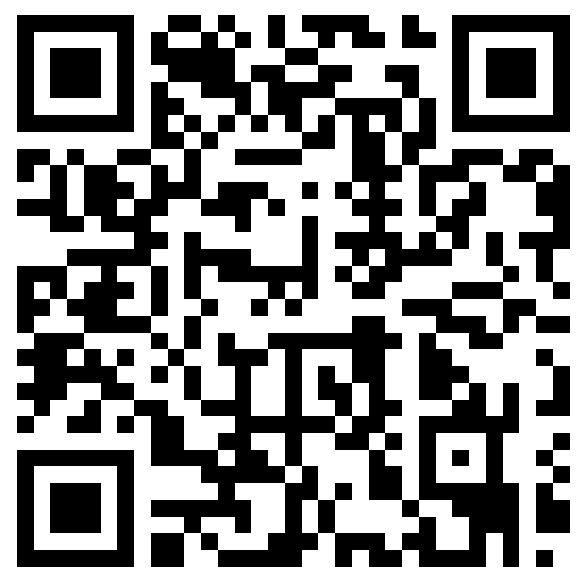

